\title{
Pengaruh latihan fisik akut terhadap kadar protein urin pada mahasiswa angkatan 2015 Fakultas Kedokteran Universitas Sam Ratulangi
}

\author{
${ }^{1}$ Paul Y. Limuria \\ ${ }^{2}$ Hedison Polii \\ ${ }^{2}$ Vanda D. Doda \\ ${ }^{1}$ Kandidat Skripsi Kedokteran Universitas Sam Ratulangi Manado \\ ${ }^{2}$ Bagian Fisiologi Fakultas Kedokteran Universitas Sam Ratulangi Manado \\ Email: paulyoke12176@yahoo.com
}

\begin{abstract}
Acute physical exercise is an exercise that is performed in a short time, it was performed only for a few minutes or $<30$ minutes. Physical exercise will cause some changes in the body, such as increased levels of urinary protein. Increased levels of urinary protein generally occurs in people with kidney disease, so that medical practitioners are often mistaken about this. This is because when doing physical exercise occurs decreases blood flow to the kidneys and cause disruption of glomerular and renal tubular function. This situation is not dangerous because it is only temporary, and reversible. In the previous studies, there is still controversy about the effect of acute physical exercise on levels of urinary protein. Based on that, researchers interested to know the impact of acute physical exercise kinds of anaerobic (sprint) towards levels of urinary protein. This study used an experimental design on one group pre-post test. Subjects were 30 male students who are in the Faculty of Medicine Sam Ratulangi. Urine protein levels assessed before and after sprint. The results obtained were processed using Wilcoxon Signed Ranks test. On the results, there was a significant increase of urinary protein $(\mathrm{p}=0,00)$ after performing an acute physical exerise (sprint).
\end{abstract}

Keywords: urine protein, acute physical exercise, student

\begin{abstract}
Abstrak: Latihan fisik akut adalah latihan yang dilakukan dalam waktu yang singkat, sekitar beberapa menit atau $<30$ menit. Latihan fisik akan menyebabkan beberapa perubahan dalam tubuh, seperti peningkatan kadar protein urin. Peningkatan kadar protein urin umumnya terjadi pada orang dengan penyakit ginjal, sehingga tenaga kesehatan sering keliru akan hal ini. Peningkatan kadar protein urin terjadi karena pada saat melakukan latihan fisik aliran darah menuju ginjal berkurang dan menyebabkan terganggunya fungsi glomerulus dan tubulus ginjal. Keadaan ini tidak berbahaya karena hanya bersifat sementara, dan reversibel. Pada penelitian-penelitian sebelumnya masih terdapat kontroversi tentang pengaruh latihan fisik akut terhadap kadar protein urin. Hal ini membuat peneliti tertarik untuk mengetahui pengaruh latihan fisik akut jenis anaerobik (sprint) terhadap kadar protein urin. Penelitian ini menggunakan desain penelitian eksperimental dengan rancangan pre-post one group test. Subjek berjumlah 30 orang mahasiswa laki-laki yang berada di fakultas kedokteran universitas sam ratulangi. Kadar protein urin dinilai terlebih dahulu sebelum melakukan sprint, setelah melakukan sprint kadar protein urin dinilai kembali. Hasil yang didapatkan diolah dengan menggunakan uji Wilcoxon Signed Ranks. Pada hasil penelitian didapatkan peningkatan yang signifikan $(p=0,00)$ kadar protein urin setelah melakukan latihan fisik akut (sprint).
\end{abstract}

Kata kunci: protein urin, latihan fisik akut, mahasiswa

Latihan fisik merupakan hal yang sudah tidak asing lagi bagi masyarakat. Latihan fisik yang dilakukan dengan benar, teratur, dan menyenangkan dapat memperbaiki dan 
menghambat penurunan fungsi organ tubuh, menyehatkan tubuh serta meningkatkan daya tahan tubuh terhadap penyakit infeksi. ${ }^{1}$ Latihan fisik selain meyehatkan tubuh secara jasmani, melakukan latihan fisik juga dapat menghilangkan penat dan stres. $^{2}$ Hidup sehat dapat dicapai dengan meningkatkan latihan fisik. ${ }^{3}$ Lebih dari dua ratus lima puluh ribu kematian pertahun, dan 12\% total tersebut dikaitkan dengan kurangnya latihan fisik. ${ }^{4}$ Sebuah studi mengatakan bahwa dengan meningkatkan latihan fisik sebanyak $10 \%$, dapat mencegah kematian sebanyak 533.000 jiwa/tahun, jika ditingkatkan sebanyak 25\%, 1.300 .000 kematian dapat dicegah. ${ }^{5}$

Berdasarkan berat ringan intensitasnya latihan fisik dapat dibagi menjadi 3 kelompok yaitu latihan fisik ringan, sedang, dan berat. Contoh latihan fisik intensitas ringan adalah bermain golf, bowling, dan panahan. Latihan fisik intensitas sedang meliputi atletik, bulutangkis, bola basket, hockey, soft ball, tenis meja, tenis, senam, sepakbola. Latihan fisik intensitas berat meliputi renang, balap sepeda, tinju, lari sprint, dan lari marathon. ${ }^{6}$ Berdasarkan durasi latihannya latihan fisik dapat dibagi menjadi 2, yaitu latihan fisik akut dan latihan fisik kronis. Latihan fisik akut adalah latihan yang dilakukan dalam waktu yang singkat, hanya beberapa menit saja atau $<30$ menit. Contoh latihan fisik akut antara lain melakukan setengah jam cross training, melakukan beberapa menit skipping, dan lari sprint. ${ }^{7}$ Latihan fisik kronis adalah latihan yang dilakukan dalam waktu yang lama. Contoh latihan fisik yang dapat dilakukan dalam waktu yang lama adalah berjalan cepat, jogging, bersepeda, hiking, dan lain-lain. ${ }^{8}$ Latihan fisik juga dapat dibagi berdasarkan sumber tenaganya yaitu latihan fisik aerobik dan latihan fisik anaerobik, latihan fisik aerobik biasanya merupakan latihan fisik dengan intensitas ringan-sedang yang dapat dilakukan secara kontinyu dalam waktu yang cukup lama. Latihan anaerobik merupakan latihan fisik dengan intensitas berat yang membutuhkan energi yang cepat dalam waktu yang singkat namun tidak dapat dilakukan secara kontinyu untuk durasi waktu yang lama. Lari sprint merupakan salah satu contoh latihan fisik akut yang membutuhkan energi yang cepat dalam waktu yang singkat (anaerobik). ${ }^{9}$

Latihan fisik akan menyebabkan beberapa perubahan dalam tubuh, seperti peningkatan kadar protein urin. Peningkatan kadar protein urin umumnya terjadi pada orang dengan penyakit ginjal, sehingga tenaga kesehatan sering keliru akan hal ini. Peningkatan ekskresi protein yang berlebihan pada urin setelah latihan fisik pertama kali dilaporkan pada tahun 1878 pada tentara yang melakukan latihan fisik berat. Hal ini dikarenakan pada saat melakukan latihan fisik aliran darah menuju ginjal berkurang dan menyebabkan terganggunya fungsi glomerulus dan tubulus ginjal. Keadaan ini tidak berbahaya karena hanya bersifat sementara, dan reversibel. Organ yang bertanggung jawab pada keadaan ini adalah ginjal. Ginjal mempunyai peran penting mengatur keseimbangan air dan elektrolit di dalam tubuh dan mempertahankan keseimbangan asam basa dengan mengsekresikannya. ${ }^{10}$

Telah dilakukan beberapa penelitian untuk mengetahui pengaruh latihan fisik terhadap kadar protein urin. Kohanpour ${ }^{11}$ pada tahun 2011 melakukan penelitian pada 10 pemain bola yang melakukan latihan fisik kronis jenis aerobik, yaitu berlari selama 30 menit dengan intensitas yang berbeda, 50, 70, dan $85 \%$ dari total heart rate. Sebelum dan 20 menit sesudah melakukan latihan fisik, kadar protein dalam urin dinilai. Pada latihan dengan intensitas 50\%, dan 70\% tidak terjadi peningkatan yang signfikan kadar protein urin. Pada latihan dengan intensitas 80\% terjadi peningkatan yang bermakna kadar protein urin. Sanavi ${ }^{12}$ pada tahun 2008 juga melakukan penelitian pada 18 atlet karate. Subjek melakukan latihan fisik akut yaitu melakukan pertandingan karate sebanyak 3 ronde, masing-masing ronde 3 menit dengan waktu istirahat 10 menit tiap ronde. Sampel urin diambil sebelum dan sesudah subyek melakukan pertandingan karate. 
Didapati peningkatan kadar protein urin total dan albumin yang signifikan di dalam urin. Pada tahun 2012 Kohanpour ${ }^{13}$ kembali melakukan penelitian pada 10 atlet karate yang diberikan latihan fisik akut yaitu bertanding karate selama 2 menit. Kadar protein urin dinilai sebelum dan sesudah bertanding. Uji yang digunakan adalah uji $t$ berpasangan. Kohanpour mendapati terdapat peningkatan kadar protein urin total setelah melakukan pertandingan karate, tetapi peningkatan yang terjadi tidak signifikan secara statistik ( $p=0,184)$. Penelitian lain juga dilakukan Forootan $^{14}$ pada tahun 2014 yang melakukan penelitian pada 21 subjek yang tidak terlatih (bukan atlet), yang terbagi menjadi 10 subjek di grup kontrol dan 11 subjek di grup eksperimental. Sampel urin diambil sebelum dan sesudah grup eksperimental melakukan latihan fisik akut jenis aerobik (lompat tali) dengan intensitas $40-70 \%$ maximum heart rates yang dilakukan secara kontinyu selama 8 minggu. Hasil yang didapatkan adalah tidak terdapat peningkatan yang signifikan.

Terdapat kontroversi dari penelitianpenelitian diatas. Pada penelitian yang dilakukan Sanavi (2008) didapati peningkatan yang signifikan kadar protein urin setelah diberikan latihan fisik akut (pertandingan karate). Hal ini berbeda dengan yang didapati oleh Kohanpour ${ }^{11}$ pada tahun 2012. Kohanpour mendapati tidak terjadi peningkatan kadar protein urin yang signifikan setelah melakukan latihan fisik akut (pertandingan karate). Pada penelitian yang dilakukan Forootan tidak terdapat peningkatan yang bermakna kadar protein urin setelah latihan fisik akut jenis aerobik (lompat tali) dengan intensitas $40 \%-70 \%$ maximum heart rates. Berdasarkan kontroversi ini peneliti tertarik untuk mengetahui pengaruh latihan fisik akut (sprint) terhadap kadar protein urin.

\section{METODE PENELITIAN}

Jenis penelitian yang dilakukan bersifat eksperimental lapangan dengan rancangan pre-post one group test. Penelitian ini dilaksanakan pada bulan
November 2015. Tempat penelitian di Fakultas Kedokteran di Kleak dan di lapangan auditorium Unsrat. Populasi penelitian ini ialah mahasiswa fakultas kedokteran Unsrat angkatan 2015. Sampel penelitian diambil dari bagian populasi yang sesuai dengan kriteria inklusi, seperti berjenis kelamin laki-laki, usia 17-19 tahun, dalam kondisi sehat dan bugar saat akan dilaksanakan penelitian, bersedia menjadi subjek penelitian dan menandatangani informed consent.

Kadar protein urin dinilai sebelum dan sesudah melakukan lari sprint menggunakan uji carik celup. Sebelum penelitian dilaksanakan subjek diedukasi untuk menjauhi hal-hal yang dapat mempengaruhi penelitian, seperti tidak mengkonsumsi makanan tinggi protein, tidak mengkonsumsi tinggi kafein, membuang urin pagi sebelum penelitian dilakukan, dan tidak melakukan aktivitas fisik berlebihan sebelum penelitian dilakukan.

Definisi operasional latihan fisik akut pada penelitian ini adalah lari sprint. Lari sprint atau lari jarak pendek pada penelitian ini adalah berlari menempuh jarak $200 \mathrm{~m}$. Lari sprint dilakukan di lapangan Auditorium Unsrat. Kadar protein urin normal dengan pengambilan urin secara random tidak lebih dari $20 \mathrm{mg} / \mathrm{dl}$. Urin yang diperiksa pada penelitian ini adalah urin sewaktu (random), dan urin yang diambil adalah urin aliran tengah (midstream)

\section{HASIL PENELITIAN}

Sampel diambil dari sebagian populasi yang telah memenuhi kriteria inklusi dan diperoleh sebanyak 30 subjek laki-laki.

\section{Karakteristik umur subjek}

Kelompok umur yang paling banyak adalah kelompok umur 17 tahun sebanyak 16 subjek (53,3\%), diikuti oleh kelompok umur 18 tahun sebanyak 13 subjek (43,3\%), dan yang paling sedikit adalah kelompok umur 19 tahun sebanyak 1 subjek $(3,3 \%)$ 
Tabel 1. Karakteristik umur subjek

\begin{tabular}{ccc}
\hline Umur & $\mathrm{n}$ & $\%$ \\
\hline 17 & 16 & 53,3 \\
18 & 13 & 43,3 \\
19 & 1 & 3,3 \\
\hline
\end{tabular}

Hasil penilaian kadar protein urin sebelum latihan fisik akut (sprint)

Didapatkan hasil pemeriksaan kadar protein urin sebelum melakukan lari sprint. 19 subjek memiliki hasil 0-15 mg/dl, 9 subjek memiliki hasil 15-30 mg/dl, dan 2 subjek memiliki hasil kadar protein urin 30-100 mg/dl.

KADAR PROTEIN URIN SEBELUM

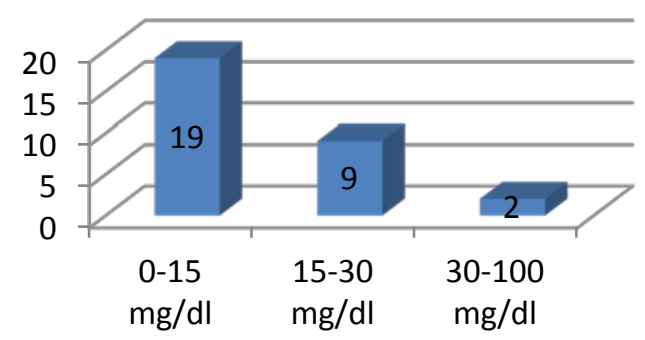

Gambar 1. Hasil kadar protein urin sebelum sprint

Hasil penilaian kadar protein urin sesudah latihan fisik akut (sprint)

Didapatkan hasil pemeriksaan kadar protein urin setelah lari sprint. 1 subjek mendapatkan hasil 0-15 mg/dl, 16 subjek mendapatkan hasil 15-30 mg/dl, dan 11 subjek mendapatkan hasil 30-100 mg/dl, dan 2 subjek mendapatkan hasil 100-300 $\mathrm{mg} / \mathrm{dl}$.

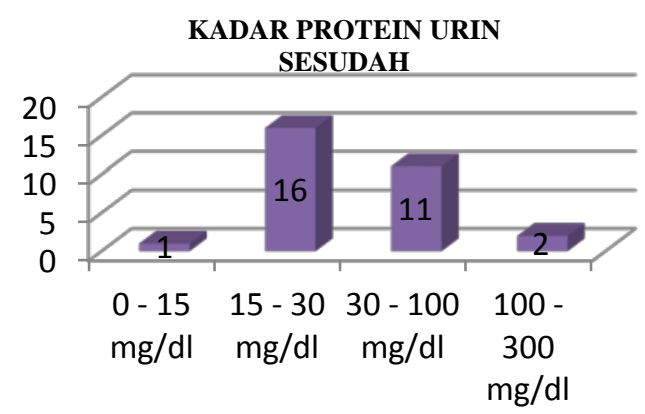

Gambar 2. Hasil kadar protein urin setelah sprint
Rata-rata kadar protein urin sebelum dan sesudah latihan fisik akut (sprint)

Berdasarkan hasil olah data (gambar), didapatkan nilai rata-rata kadar protein urin sebelum sprint sebesar 6,50 $\mathrm{mg} / \mathrm{dl}$, sedangkan nilai rata-rata kadar protein urin setelah sprint sebesar $25,67 \mathrm{mg} / \mathrm{dl}$.

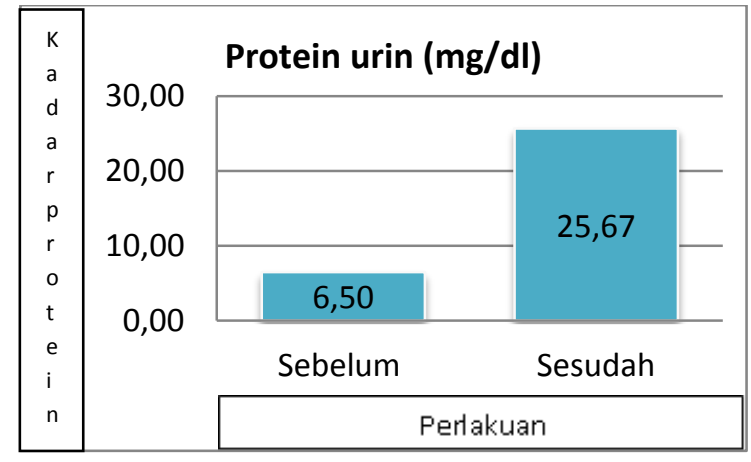

Gambar 3. Rerata kadar protein urin sebelum dan sesudah sprint

Rata-rata peningkatan kadar protein urin sebelum dan sesudah latihan fisik akut (sprint)

Berdasarkan hasil olah data (tabel 2) rata-rata peningkatan protein urin adalah $19,7 \mathrm{mg} / \mathrm{dl}$

Tabel 2. Rata-rata peningkatan

\begin{tabular}{llrrr} 
& $\mathrm{n}$ & $\min$ & $\max$ & mean \\
\hline peningkatan & 30 & 0 & 70 & 19,17 \\
\hline
\end{tabular}

\section{DISKUSI}

Pada pemeriksaan kadar protein urin sebelum sprint (Gambar 1), 19 subjek mendapatkan nilai 0-15 mg/dl dan 9 subjek mendapatkan nilai $15-30 \mathrm{mg} / \mathrm{dl}$. Hasil ini menunjukkan bahwa pada usia 17-19 tahun fungsi ginjal masih bekerja dengan baik sehingga kadar protein urin yang didapat sebelum melakukan sprint cenderung normal. Sel-sel ginjal mulai mati sejak usia mencapai 20 tahun, namun penyusutan secara bertahap umumnya tidak terlihat sampai usia mencapai 40 tahun. Pada saat usia mencapai 80 tahun, ginjal kehilangan sepertiga massanya. Sekitar 5\% glomeruli mengalami kelainan pada usia 40 tahun, dan $37 \%$ glomeruli mengalami kelainan 
pada usia 90 tahun. Pada saat usia mencapai 75 tahun terjadi penurunan GFR dari sekitar $125 \mathrm{ml} /$ menit menjadi sekitar $60 \mathrm{ml} /$ menit. Hal ini yang menyebabkan pada lanjut usia sering didapati kadar protein urin yang tinggi. ${ }^{15}$

Pada pemeriksaan kadar protein urin sebelum sprint (Gambar 1), terdapat 2 subjek (6,7\%) yang memiliki nilai kadar protein urin relatif tinggi, yaitu sekitar 30$100 \mathrm{mg} / \mathrm{dl}$. Hal ini bisa disebabkan oleh beberapa faktor, antara lain dehidrasi dan konsumsi makanan tinggi protein sebelum penelitian dilakukan. ${ }^{16}$

Berdasarkan data yang didapatkan, 5 subjek $(16,7 \%)$ tidak mengalami perubahan kadar protein urin sebelum dan sesudah latihan fisik akut (sprint). Hal ini bisa disebabkan karena terjadi false negative pada pemeriksaan kadar protein urin setelah latihan fisik akut (sprint). Faktorfaktor yang memicu terjadinya false negative adalah urin yang terlalu encer (UO $>5,0 \mathrm{~L} / \mathrm{hari}$ ) dan urin yang bersifat asam $(\mathrm{pH}<5){ }^{17}$ Urin yang terlalu encer dapat disebabkan karena konsumsi air yang banyak sebelum melakukan penelitian. Urin yang bersifat asam dapat disebabkan beberapa kondisi, antara lain dehidrasi, diare, dan asidosis. ${ }^{18}$

Pada penelitian yang dilakukan Kohanpour pada tahun 2011 kepada 10 atlet sepakbola yang diberikan latihan fisik kronis jenis aerobik yaitu berlari selama 30 menit dengan intensitas yang berbeda, $50 \%, 70 \%$, dan $85 \%$ dari total heart rate. Terjadi peningkatan yang signifikan kadar protein urin pada intensitas $85 \% .{ }^{11} \mathrm{Hal}$ ini membuktikan bahwa intensitas latihan fisik sangat berpengaruh terhadap kadar protein urin. Penelitian lain juga dilakukan oleh Arabpourian yang melakukan penelitian terhadap 15 atlet wanita dan 30 subjek bukan atlet. Jenis latihan yang diberikan adalah latihan fisik kronis jenis aerobik yaitu jogging $1600 \mathrm{~m}$. Pemeriksaan dilakukan sebelum dan sesudah melakukan latihan fisik. Arabpourian mendapati peningkatan protein urin pada kedua kelompok subjek setelah melakukan latihan fisik kronis. ${ }^{19}$ Pada penelitian yang dilakukan oleh peneliti didapatkan peningkatan kadar protein urin yang signifikan dengan nilai $p=0,000$ setelah melakukan latihan fisik akut jenis anaerobik dengan intensitas berat (sprint), dengan rata-rata peningkatan 19,7 mg/dl. Peningkatan yang bermakna ini dapat terjadi karena subjek mengikuti penelitian ini dengan baik dan serius. Subjek sudah diedukasi sebelumnya untuk melakukan hal-hal berikut yang dapat mempengaruhi penelitian, seperti membuang urin pagi, tidak memakan makanan tinggi protein sebelum melakukan penelitian, tidak mengkonsumsi obat-obat yang dapat mempengaruhi kadar protein urin, tidak mengkonsumsi kafein berlebihan dan melakukan teknik lari sprint secara benar. Hasil yang peneliti dapatkan konsisten dengan hasil penelitian yang didapati Sanavi $^{12}$ pada tahun 2008 yang mendapatkan terdapat peningkatan yang signifikan kadar protein urin setelah melakukan latihan fisik akut yaitu bertanding karate sebanyak 3 ronde, masing-masing ronde 3 menit. Hasil yang peneliti dapatkan ini tidak konsisten dengan penelitian yang dilakukan Kohanpour 2012. Perbedaan hasil yang didapat ini bisa saja terjadi karena latihan fisik akut yang diberikan Kohanpour adalah latihan fisik intensitas ringan-sedang yaitu bertanding karate 1 ronde selama 2 menit. ${ }^{13}$ Penelitian yang dilakukan Forootan $^{14}$ yang memberikan latihan fisik akut intensitas sedang (40-70\% dari maksimum herat rate) tidak mendapatkan peningkatan kadar protein urin yang signifikan. Dapat disimpulkan bahwa terdapat pengaruh latihan fisik akut dan kronis terhadap kadar protein urin, tetapi peningkatan yang terjadi tergantung dari intensitas latihan yang diberikan.

Pada saat seseorang melakukan latihan fisik akut jenis anaerobik, pembuluh darah pada ginjal akan berkonstriksi dan pembuluh darah pada otot-otot akan berdilatasi. Oksigen yang disalurkan tidak cukup untuk memenuhi kebutuhan energi secara cepat, karena itu ATP harus digunakan untuk memenuhi kebutuhan 
energi. Hal ini yang menyebabkan pada latihan fisik anaerobik tetap terjadi perubahan permeabilitas glomerulus dan disfungsi tubulus yang memicu peningkatan kadar protein urin. ${ }^{11,20}$

Hasil penelitian ini menunjukkan bahwa terjadi peningkatan kadar protein urin. Nilai signifikansi (p) dari hasil uji statistik Wilcoxon Signed Ranks yaitu 0,00 lebih kecil dari nilai alpha $(\alpha=0,05)$, sehingga menunjukkan adanya pengaruh yang signifikan latihan fisik akut (sprint) terhadap kadar protein urin.

Kendala dalam penelitian ini adalah peneliti tidak bisa mengontrol hal-hal yang dapat mempengaruhi data seperti makanan yang dikonsumsi, aktivitas fisik, dan kecukupan istirahat subjek sebelum penelitian dilakukan. Hal ini disebabkan oleh keterbatasan dana, waktu, dan tenaga. Untuk mendapatkan hasil yang terbaik harus dilakukan karantina pada subjek penelitian.

\section{SIMPULAN DAN SARAN}

Berdasarkan hasil penelitian dan bahasan dapat disimpulkan bahwa terdapat pengaruh bermakna latihan fisik akut (sprint) terhadap kadar protein urin.

Perlu dilakukan penelitian lebih lanjut dengan memberikan latihan fisik intensitas berbeda.

\section{UCAPAN TERIMA KASIH}

Ucapan terima kasih disampaikan pada dr. Herlina Wungouw, MsAppSc, MmedEd, dr. Sylvia Marunduh Mmed, AIFM, dan semua pihak yang baik secara langsung maupun tidak langsung telah menumbuhkan ide atau gagasan dalam pemikiran penulis sehingga dapat menyelesaikan artikel ini.

\section{DAFTAR PUSTAKA}

1. Yuliarto H. Latihan fisik dan kekebalan tubuh. Medikora. 2008;4:47-65

2. Silverthorn UD. Fisiologi manusia sebuah pendekatan terintegrasi. Jakarta: EGC, 2013; p.870-80.

3. World Health Organization. Global recommendations on physical activity for health [homepage on the internet]. c2010 [cited 2015 oct 5]. Avaible from:

http://whqlibdoc.who.int/publications /2010/9789241599979_eng.pdf

4. Roizen M. How much do people exercise [homepage on the internet]. Nodate [cited 2015 oct 1]. Avaible from: https://www.sharecare.com/health/fit ness-goals/how-much-do-peopleexercise

5. Park A. Lack of exercise as deadly as smoking [homepage on the internet]. c2012 [updated 2012 Jul 18; cited 2015 Oct 3]. Avaible from: http://healthland.time.com/2012/07/1 8/lack-of-exercise-as-deadly-assmoking-study-finds/

6. Direktori UPI. Klasifikasi olahraga dan proses pemecahan energi dalam tubuh [homepage on the internet]. Nodate [cited 2015 Oct 5]. Avaible from: http://file.upi.edu/Direktori/FPOK/JU R._PEND._OLAHRAGA/195906281 989012-

LILIS_KOMARIYAH/MODUL_IK OR.pdf

7. Acute exercise [homepage on the Internet]. Nodate [cited 2015 Oct 5]. Avaible from:

http://www.answers.com/Q/What_is_ acute_exercise

8. Tangerine. Chronic exercise [homepage on the internet]. c2011 [updated 2011 Jan 11; cited 2015 Oct 7]. Avaible from:

http://www.acne.org/messageboard/to pic/286900-chronic-exercise/

9. Dwi L. Hakekat lari jarak pendek [homepage on the Internet]. c2012 [cited 2015 Oct 5]. Avaible from: http://eprints.uny.ac.id/7747/3/BAB\% 20II\%20-\%2008601244068.pdf

10.Snell SR. Anatomi klinik. Jakarta: EGC, 2006; p.250.

11.Kohanpour A, Vatandost M, Zolfaghari F, Peeri M, Mirsepasi M, Mirsepasi $\mathbf{Z}$, et al. the effect of different intensities of sub maximal aerobic exercise on proteinuria in young football players. Research of biological science. 2011;11:590-596.

12.Sanavi S, Afshar $\mathbf{R}$, Ahmadzadeh $M$. The pattern of proteinuria following karate (kumite) competitions 
[homepage on the internet]. c2008 [updated 2008 May 21; cited 2015 Nov 5]. Avaible from: http://trabajos.cin2011.uninet.edu/340 /sanavi-karate.pdf

13.Kohanpour A, Vatandoust M, Mirsepasi M, Nasirzade A, Kohanpour $M$, Boostani H, et al. Effect of a karate competition on urinary excretion of proteins with high molecular weight (glomerular proteinuria) in young male karatekas. Research of biological sciences. 2012;6:660-664.

14.Forootan A, Taghian F, Mortazavi M. Determining the effects of eight weeks of rope skipping sport on proteinuria changes among 9-12 years old non-athletic boys in Khansar school. International journal of sports studies. 2014;4:1062-1066.

15.Shier D, Butler J, Lewis R. Human anatomy and physiology. New York: McGrawHill, 2001; p.849.

16.Cadogan M. Urinalysis [homepage on the Internet]. c2014 [updated 2014 Jan 4; cited 2016 Jan 4]. Avaible from: http://lifeinthefastlane.com/investigati ons/urinalysis/

17.Tortora J, Derrickson B. Principles of anatomy and physiology. United States: John Wiley \& Sons, 2009; p.1029.

18.Krucik G. Urine $\mathrm{pH}$ level test [homepage on the Internet]. c2011 [updated 2011 Jun 11; cited 2016 Jan 8]. Avaible from:

http://www.healthline.com/health/uri ne-ph\#Results4

19.Arabpourian M, Rahimi A, Sarshin A. Effect of 1600-meter run on changes in proteinuria, creatinine and hematuria levels during recovery time among young female athletes and non-athletes. Ephemerajournal. 2015;27:1.

20.Sudoyo W, Setiyohadi B, Alwi I, Simadibrata K, Setiati S. Buku ajar ilmu penyakit dalam. Jakarta: Interna Publishing, 2009; p.957. 